\title{
A biztonságtudatosság fogalma, fejlődése nemzetbiztonsági, terrorelhárítási és magánbiztonsági szempontból
}

\author{
The Concept and Evolution of Security Awareness in National \\ Security, Counterterrorism and Private Security
}

Cikkükben a szerzők összehasonlító megközelitést alkalmazva mutatják be a biztonságtudatosság aktuális kérdéskörét. A biztonság fogalmából indulnak ki, majd áttérnek a biztonságtudatosság fogalmára, és a nemzetbiztonsági szolgálatok vonatkozásában vázolják fejlödésének jelentős mozzanatait. Ezt követően röviden felvillantják a rendőri bünmegelőzést, majd áttérnek a biztonságtudatositás terrorelhárítási szempontú ismertetésére. A cikk a téma magánbiztonsági szempontú bemutatásával és egy nemzetközi környezetböl vett esettanulmánnyal fejeződik be. Az összegzésben a szerzők hitet tesznek amellett, hogy a hasonló módszertanon túl, a nemzetbiztonsági, terrorelhárítási és magánbiztonsági biztonságtudatosság egymást támogatja és kiegészíti.

Kulcsszavak: biztonságtudatosság, nemzetbiztonság, terrorelhárítás, magánbiztonság, rendőri bünmegelözés, szállodaláncok biztonsága

In their article, the authors present - using a comparative approach - the current issue of security awareness. In doing so, they start from the concept of security, then move on to the concept of security awareness, and outline the significant moments of its development in relation to national security services. They then briefly flash police crime prevention and then move on to the security awareness presentation from a counterterrorism perspective. The article concludes with a presentation of the topic from a private security perspective and a case study in an international context.

Vezető, Terrorelhárítási Központ, Társadalmi Kapcsolatok Osztály; e-mail: jasenszky.nandor@tek.gov.hu Adjunktus, Nemzeti Közszolgálati Egyetem Polgári Nemzetbiztonsági Tanszék; e-mail: Regenyi.Kund@uninke.hu

R. alezredes, mesteroktató, Nemzeti Közszolgálati Egyetem Rendészettudományi Kar Magánbiztonsági és Önkormányzati Rendészeti Tanszék; doktori hallgató, Rendészettudományi Doktori Iskola; e-mail: lippai. zsolt@uni-nke.hu 
In the summary, the authors believe that, in addition to a similar methodology, national security, counterterrorism, private security and security awareness support and complement each other.

Keywords: security awareness, national security, counterterrorism, private security, police crime prevention, security of hotel chains

\section{Gondolatok a biztonságról}

A biztonság az egyének, az emberi közösségek, a különböző társadalmak talán egyik legrégibb igénye és vágya. A biztonság igényét korábban megtörtént vagy folyamatosan jelen lévő, nemkívánatos veszélyes események megtörténte vagy történése váltja ki. A közösség igyekszik tenni azért, hogy a helyzet megváltozzon és a kívánatos rend helyreálljon. Ebből a cselekménysorból, az adott válaszokból alakul ki a védelem. A védelmi intézkedések a konkrét, azonnal kezelendő eseményekre adott direkt válaszok. Az állandósuló ilyen irányú feladatok hozták, hozzák létre azokat a védelmi - nemzetvédelmi és rendvédelmi - szervezeteket, amelyek hivatásszerüen foglalkoznak a problémák kezelésével. Ezektől a szakmai közösségektől elvárható volt, hogy ne csak az akutan jelentkező nemkívánatos eseménnyel foglalkozzanak, hanem azt összefüggéseikben, rendszerben vizsgálják. A további bemutatás érdekében maradunk az akut kifejezés használatánál, amely leginkább az egészségügyi, orvosi ellátási nyelvezet része. Nézzük az orvoslás múködési logikáját:

- tünetek azonosítása;

- diagnózis felállítása;

- tüneti kezelés;

- gyógyítás;

- utókezelés;

- megelőzés.

Amennyiben ezt a közérthető egészségügyi „kezelési” sort lefordítjuk - például a terrorelhárítás nyelvére, akkor a következőt látjuk:

- tünetek = észlelés, detektálás;

- diagnózis = elemzés, értékelés;

- tüneti kezelés = felderítés, felszámolás;

- gyógyítás = az okok feltárásával az ellenséges lehetőségek korlátozása, megszüntetése;

- utókezelés, megelőzés = társadalmi párbeszéd, tájékoztatás, nevelés, oktatás, a biztonságtudatos magatartás kialakítása, karbantartása és fejlesztése.

Jelen cikk a biztonságtudatossággal kapcsolatos témák tárgyalását tǔzte ki célul. 


\section{A biztonságtudatosság mint fogalom és jelenség kialakulása}

A biztonságtudatosság, vagy régebbi megjelöléssel awareness tevékenység, a 2010-es évek végén felértékelődni látszik a címben említett, tágabb értelemben vett rendvédelmi szervek működésében. A szerzők ezért elérkezettnek látták az időt, hogy bemutassák a biztonsági tudatosság fogalmát, és röviden vázolják annak tartalmát a megelőzésre törekvő állami, illetve magánbiztonsági szolgálatok tevékenységében.

Első mozzanatként a fogalom tartalmát érdemes körüljárni. Ha az angol szó jelentéséből indulunk ki, úgy az awareness legtalálóbb fordítása valóban a tudatosság lesz. Ha a később vázolandó tevékenységet vizsgáljuk, akkor az említett tudatosság ehelyütt nem más, mint a célul kitűzött állapot, tudniillik az a fajta magas szintű (biztonsági) tudatosság, amely a szolgálatok komplex felvilágosító, oktatási tevékenysége eredményeképpen jön létre. A fogalmat tovább vizsgálva azt is elmondhatjuk, hogy annak tartalmi eleme a tudatosságból fakadó cselekvés is, azaz a biztonsági eljárások és ajánlások megismerésén túl annak betartása; illetve ha ezek megsérülni látszanak, úgy a szolgálatok tájékoztatása is.

Tágabb értelemben a fogalomhoz soroljuk azokat a múvészi vagy legalábbis szórakoztató igénnyel készült irodalmi és/vagy filmalkotásokat is, amelyeknek járulékos célja, hogy pozitív képet alkossanak, mutassanak honvédelmi, rendvédelmi és nemzetbiztonsági szervezetekről, megteremtve ezzel esetleges megkeresésük, kapcsolatfelvételük esetére a fogadókészséget.

Ha tehát tartalmi definíció megalkotására vállalkozunk, úgy az a következőképpen hangzik. Biztonsági tudatosság alatt a tágabb értelemben vett rendvédelmi és magánbiztonsági szervek komplex, plakátok, emléktárgyak előállításában és átadásában; előadások, filmvetítések, e-learning-anyagok létrehozatalában és megtartásában megnyilvánuló oktatási képzési tevékenységet értjük. Eredményeképpen létrejön a biztonsági kihívásokat jól ismerő, a megelőzéshez és elhárításhoz szükséges magatartási formákat szintén ismerő és a gyakorlatban azokat alkalmazó, implementáló attitűd, viszonyulás, eljárásrend, amely kiterjed a biztonság sérülése esetén a rendvédelmi szervek megkeresésére, tájékoztatására is.

(Közbevetett megjegyzés, hogy a biztonságtudatosság helyett érdemes lenne más terminus technicust használni, így például javasoljuk a biztonsági tudatosítás vagy az érzékenyítés fogalmának alkalmazását, tekintve, hogy ez sokkal kifejezőbb az említett szerzők által fontosnak tartott tevékenység vonatkozásában.)

\section{A biztonságtudatosság rövid áttekintése nemzetbiztonsági vonatkozásban}

Térjünk át a biztonsági tudatosítás kialakulására és fejlődésére. A biztonsági tudatosítás megjelenése mögött az a nyilvánvaló körülmény áll, hogy a szolgálatok egyetlen korban sem voltak képesek valamennyi ellenérdekelt vagy potenciálisan ellenérdekelt tevékenység észlelésére. Annak érdekében, hogy munkájukat hatékonyan tudják végezni, szükségük volt potenciális fenyegetéseket hordozó személyekre vonatkozó 
jelzésekre, illetve indokolt volt biztonságtudatos magatartás kialakításával megnehezíteni az ellenérdekelt fél dolgát.

Ez napjainkban is így van. A nemzetbiztonság, a terrorelhárítás, a bünüldözés, a szervezett búnözés elleni harc információéhsége szinte csillapíthatatlan. Az elkövetett cselekmények modus operandijának változása - magasabb szervezettség, intenzívebb konspiráció, a magányos elkövetők térnyerése, a terrorizmus és a szervezett bűnözés összefonódása - egyre inkább igényli, hogy a társadalomból, a kis közösségekből érkezzenek információk, mert sok esetben ezek az adatmorzsák a megoldáshoz vezető út iránypontjai. Ahhoz, hogy ezekből a forrásokból a felsorolt szakmai területek információhoz jussanak, élvezniük kell az emberek, a társadalom bizalmát. A bizalom roppant illékony. Megszerzéséhez, és főleg a megtartásához, sok tennivaló vár az érintettekre. Átlátható, a közösség által megérthető tevékenység, gyors és tényszerű szakmai kommunikáció az alapjai a bizalom építésének. Ugyanakkor a bizalom rombolásában - ami sokkal, de sokkal gyorsabb, mint az építés - megkerülhetetlen a „nyilvánosságcsinálók” szerepe. Rögtön szögezzük le, hogy nem azzal van a baj, ha foglalkoznak ezekkel a kérdésekkel, még azzal sem, ha kritikusok, hanem az esetenként ellenőrizetlen, torzított, olykor félrevezető állításokkal. A felelőtlenül pellengérre állított hatóságok minősítésével a „,hozzá nem érto””, „feladatát megoldani nem tudó”, de legalább „semmit nem tévő” jelzők hihetetlenül gyorsan erodálják a nemzetbiztonsági és rendvédelmi szervek bizalmi bázisát. Határozott álláspontunk, hogy a minőségi politizálást és újságírást a felelősségteljességnek is jellemeznie kell.

Régebbi időszakokban a kihívásokat hordozó személyek azonosítása, hatóságok részére való feljelentése volt az előtérben. Már a középkor nagy háborúiban is megfigyelhetünk egyfajta kémpánikot. A történeti emlékezet ennek elsősorban negatívumait, túlhajtott vonásait őrizte meg. Szakmai szemmel azonban jogos az az értékelés, miszerint sikerült felkelteni az ellenérdekű kémekkel szembeni éberséget, és a bármilyen néven nevezendő szolgálatokhoz számos indító jelzés érkezett. Ennek emlékét őrzi mind a mai napig bizonyos súlyos, elsősorban államellenes és emberiségellenes búncselekményekhez kapcsolódó feljelentési kötelezettség. ${ }^{4}$

A 19. század harmadik harmadára nemcsak a modern értelemben vett nemzetbiztonsági szolgálatok jelennek meg, hanem a megelőzésre való törekvés felértékelődésével új eszközökkel bővül az awareness-tevékenység is. Ehelyütt elsősorban a plakátokat, ${ }^{5}$ illetve figyelemfelkeltő feliratokat ${ }^{6}$ emeljük ki, amelyek a korszak konfliktusaiban, így a rövid 20. századot bevezető I. világháborúban tömegével készültek. Elmondható, hogy a fennmaradt plakátok jelentős része a tágabb értelemben vett háborús propaganda céljait szolgálta mindkét oldalon, azonban a mai értelemben vett biztonsági tudatosítás céljai is jól megragadhatók. Ugyancsak az I. világháború utáni időszakra vonatkozóan említhetjük a különböző, változó igényességgel készült

Görgényi Ilona et al.: Magyar büntetőjog általános rész. Budapest, 2019. 4.2.4. fejezet (A feljelentési kötelezettség elmulasztása).

Lásd: https://pbs.twimg.com/media/C8scr59WsAAxGiQ.jpg és https://media.gettyimages.com/photos/ telling-a-friend-may-mean-telling-the-enemy-shes-not-so-dumb-careless-picture-id138603173?s=612x612 Például: lehallgatás lehetőségére való figyelmeztetés tábori telefonon: www.worthpoint.com/worthopedia/ original-wwii-hungarian-military-1817694951 
regények, ${ }^{7}$ pamfletek megjelenését is. A II. világháborúra a biztonsági tudatosítás eszköztára a filmekkel is kibővült, és elmondható, hogy ez az eszköztár jórészt napjainkig használatos.

Magyarország vonatkozásában az előbb vázolt fejlődés jól bemutatható. Az l. világháború után az önálló, független Magyarország és az önálló nemzetbiztonsági szolgálatok megjelenésével az I. világháborúban kialakult eszköztár továbbélését és fejlődését láthatjuk. A korszakból nemcsak plakátok, hanem irodalmi igényü, tágabb értelemben a biztonsági tudatosításhoz sorolható alkotások is fennmaradtak. A nemzetbiztonsági szolgálattal szorosan együttműködve, később pedig azzal szervezetileg is összevont módon létezett egy hazafias propagandáért felelős szervezet is. ${ }^{8}$

A II. világháborút követően, ideológiailag átkeretezve, a biztonsági tudatosítás tovább élt és fejlődött. Korunkra maradt emlékei közül elsősorban itt is a szélesebb közönség számára készült, biztonságtudatosítási funkciót is ellátó regényeket, illetve filmeket emelhetjük ki.

A rendszerváltást követően a biztonsági tudatosítás átmeneti időre háttérbe szorult, hogy a feladatrendszer és a küldetés egyértelművé válásával a 2000-es években újra megjelenjen, betöltve hasznos és nélkülözhetetlen szerepét.

Ma a nemzetbiztonsági szolgálatok biztonsági tudatosító tevékenységüket elsősorban az úgynevezett intézményvédelem keretében, vagy azzal szorosan együttműködve látják el. A biztonsági tudatosítás első lépéseként előadásokat rendeznek, tájékoztatókat tartanak, amelyek keretében, illetve azokhoz kapcsolódóan papíralapú vagy elektronikus tájékoztató anyagok, szórólapok átadására is sor kerül. A tájékoztatók mellett megtalálhatók a plakátok és az emléktárgyak is. A hatékonyság növelése érdekében a tájékoztatók testreszabhatók a célközönség igényeinek, illetve fenyegetettségi szintjének megfelelően.

A technika fejlődésével párhuzamosan a biztonsági tudatosítás súlypontja elsősorban az informatikai és kiberbiztonságra tevődik át. Ez a felület annyira előtérbe került, hogy önállósodott is, illetve esetenként maga a fogalom is sokak számára csak erre vonatkozik. A nemzetbiztonsági szolgálatok azonban megőrzik a biztonság és a fenyegetés komplex megközelítését. Természetes, hogy az IT-, illetve kiberbiztonsági tudatosítás mára kommercializálódott, és az e területen aktív vállalkozások tevékenységének egyik elemévé vált.

A folyamatot tovább kísérve elmondható, hogy optimális esetben biztonsági tudatosítás eredményeképpen jelzések érkeznek a szolgálatokhoz, megalapozva azok hatékony fejlődését.

Az elhárító szolgálatok eszközrendszerének egyéb elemeivel összehasonlítva igazolható az a megállapítás is, hogy a biztonsági tudatosítás egyfajta kapunyitó szerepet is betölthet, mivel ennek során a szolgálatok segítő-támogató attitűdje válik kézzelfoghatóvá.

Viszonylag ismert magyar példák Mattyasovszky Jenő Hód-könyvei, és Mág Bertalan: Öt méregfiola. Budapest, Zrínyi, 1984; vagy a Berkesi András - Kardos György szerzőpáros könyvei, például Kopjások. Budapest, Magvető, 1986.

$8 \quad$ Lásd Kádár Gyula: A Ludovikától Sopronkőhidáig. Budapest, Magvető, 1984. A részleget Somogyváry Gyula, I. világháborús veterán, hazafias könyvek szerzője (például: Virágzik a mandulafa; Ne sárgulj, füzfa!; És Mihály harcolt stb.) vezette. 


\section{Kitekintés - rendőri bünmegelőzéssel kapcsolatos tapasztalatok}

Ahhoz, hogy jobban átlássuk a helyzetet, az „idősebb rokont”, a bünmegelőzést, annak rendszerét célszerü segítségül hívni. Az egyik szerzőtárs, Jasenszky Nándor személyes élményanyagát hívjuk segítségül.

Az 1980-as évek elején a Budapesti Rendőr-főkapitányság (BRFK) Betörési Csoportjának fő profilját a kiemelt - a ma már megmosolyogtató 100000 forint és az afeletti - kárértékü, illetve a sorozatban elkövetett betörések képezték. A szakmai közösség és annak vezetői elvárták és megkövetelték, hogy a nyomozások során vizsgáljuk a lehetővé tevő körülményeket és persze azt is, hogy mit és milyen formában tehetünk ezek ellen. Csak egy példát ragadnék ki a számtalanból. Amikor 1982 márciusában megindult - a korábban Magyarországon szinte ismeretlen - hengerzártörés módszerével elkövetett lakásbetörési sorozat, az első perctől kiemelt feladat volt az elkövetés vizsgálata. A módszer gyors, egyszerü, csekély eszközigényű, nyomszegény zárnyitást tett lehetővé. A másik fontos momentum volt, hogy Magyarországon a leggyakrabban használt, úgynevezett „körte alakú” hengerzárbetétet támadta. Tapasztalatainkkal - a még zajló felderítés mellett - megkerestük a kérdéses Elzett zár gyártóját, és elkezdődött a lehetőségek vizsgálata a zárak és zárkörnyezetek átalakításáról a behatolási módszer megakadályozása érdekében. Az akkor kimunkált megoldások a mai napig élnek, és beépültek a biztonságos zárrendszerek gyártási folyamatába.

A nyolcvanas évek elején a BRFK vagyonvédelmi szakterületének szervezeti válasza is volt a betöréses lopások visszaszorítására, létrehozta a Vagyonvédelmi Tanácsadó Szolgálatát, amely a maga korában az első és egyetlen volt, ahol rendőri és megfelelő múszaki tapasztalattal is rendelkező munkatársak adtak a komplex védelmi rendszerek kialakítása érdekében tanácsokat, és kötötték össze az állampolgárokat a biztonsági szolgáltatókkal. A későbbiek során a bűnmegelőzés önálló szakterületté vált, széles körben, megfelelő szervezeti háttérrel, külső társadalmi kapcsolatrendszerrel végzik munkájukat napjainkban is.

\section{Biztonságtudatosság a terrorelhárításban}

A terrorizmussal, a terrorelhárítással a rendszerváltás előtt csak nagyon sajátos módon, szinte a nyilvánosság, a társadalom teljes kizárásával lehetett foglalkozni. Ugyan együtt éltünk vele, hiszen ha csak a modern kori terrorizmus alapkövének tekinthető 1972-es müncheni olimpiai támadásra gondolunk, vagy a Vörös Brigádok, a Vörös Hadsereg Frakció tevékenységére, ezek ismert események voltak a nyilvánosság számára is. Ugyanakkor a kétpólusú világrendben ezek olyan cselekményekként lettek tálalva, mint amelyek nálunk meg sem történhetnek. Az időszakot meghatározta a „te terroristád - az én szabadságharcosom” nézőpont szerinti - finoman fogalmazva - átpolitizált hozzáállás. 
A rendszerváltás után a helyzet alapvetően megváltozott. A magántulajdon erőteljes fejlődése, a gazdasági szerkezet átalakítása, a társadalom, a jogrendszer, a nemzetbiztonsági szervezetek, a rendvédelmi szervek kihívásainak, feladatainak változása új helyzetet teremtett. A körülmények ilyen nagymérvü, komplex változása oda vezetett, hogy a jelen tanulmányban leírt kezelési modellből a legoptimálisabb esetben is csak a tüneti kezelésig jutottunk. Ez tetten érhető volt a terrorelhárítás és a szervezett bűnözéssel való foglalkozás területén is. Nem voltak mélyreható, ok-okozati összefüggéseket feltáró elemzések, nem voltak kiérlelt javaslatok, sok esetben a társadalom és a politika is adós volt azzal, hogy mit vár el a felelős szakmai szervezetektől. Determinált volt a kapkodás, rögtönzés, a pillanatnyi felszíni problémák eseti kezelése. Ebben az időben a biztonságtudatos magatartások speciális formálása erősen háttérbe szorult, illetve inkább nem is volt. Az egyre aktívabb, öntudatosabb társadalom kialakulása, fejlődése folyamatosan fejlesztett egy nyitottabb, sokkal szélesebb alapokon nyugvó kommunikációt. A megjelenő információk mennyisége és gyorsasága egyre nagyobb mértékben befolyásolta a mindennapokat. Természetesen sokkal nagyobb teret kaptak a negatív jelenségekkel kapcsolatos felvetések is. A hirtelen sokszereplőssé váló hírverseny káros mellékhatása volt, hogy a gyorsaság és a mennyiség a hiteles tájékoztatás és a minőség rovására ment. A média a biztonságérzetet befolyásoló tényezővé vált.

A következő, szerencsés mozzanat a konszolidáció bekövetkezése, amelynek terrorelhárítási, egyben felderítési szempontból határköve és kiindulópontja a Terrorelhárítási Központ (TEK) 2010-es megalakulása. A TEK hosszú évek óta igyekszik, hogy szélesítse a párbeszédet a társadalommal. Jelenleg bizonyos célcsoportokra fókuszál, de törekszik folyamatosan bővíteni a kört a tömegtájékoztatás eszközein túl a helyszíni személyes megjelenés lehetőségével, előadások, tájékoztatók megtartásával is. Az így átadott információkkal szeretnénk elérni a biztonságtudatossági folyamat vagy körforgás kialakulását. Ennek lényege - véleményünk és tapasztalataink szerint - az egymásra épülő biztonság, a biztonsági szintek körforgása.

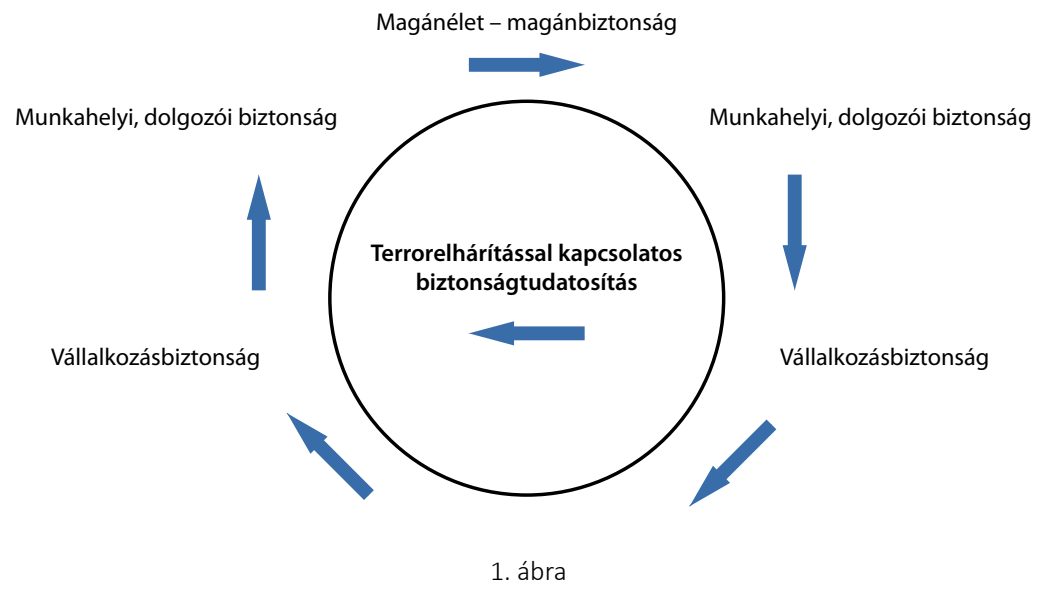

Biztonságtudatossági körfolyamat 


\section{Magánélet - magánbiztonság}

Az embereknek, közvetlen környezetüknek, családjuknak az általános biztonsággal kapcsolatos szabályaik szinte genetikailag kódoltak: a gyermek, a lakás, az értékek védelme hosszú évek tapasztalata alapján, illetve korábbi generációk által átadott szokások, szabályok által determináltak. A szabályok külső hatások által változnak, illetve változhatnak, de általában csak kis mértékben - néha csak a technikai lehetőségek fejlődése mentén - finomhangolódnak.

\section{Munkahelyi, dolgozói biztonság}

A munkahelyi, dolgozói biztonság nagymértékben befolyásolt azáltal, hogy a munkahelynek milyen a vállalati kultúrája, a foglalkoztató mennyire kitett biztonsági kihívásoknak, mennyire volt korábban érintett rendkívüli eseményekkel, illetve mennyire korszerűen előrelátó. Összetett folyamatokról beszélünk, hiszen itt már a személyes biztonságon túl megjelenik többek között a vagyonvédelem, vagy az adat- és információbiztonság és egyéb, az adott munkahelyre jellemző biztonsági igények is. A munkahelyi biztonsági kultúra már hatással lehet az egyén magánbiztonságára is.

\section{Vállalkozásbiztonság}

Fontos rögtön tisztázni, hogy a vállalkozásbiztonság nem egyenlő a vállalatbiztonsággal. Az eltérés formailag csak pár betű, de a tartalomban óriási. A vállalkozásbiztonság a vállalkozás teljes múködési vertikumáért felel. A múködési környezet, az emberi tényezők, a munkavállalók, a beszállítók, alvállalkozók, a termékek piaci helyzete, versenytársfigyelés, kereskedelem, marketing, szállitásbiztonság folyamatos monitoringozása, a belső és külső visszaélésekkel szemben való fellépés, a folyamatos működés, szolgáltatás vagy termelés biztosítása is a feladata. Nagyon széles körű, sok területet átfogó tevékenység. A nemzetközi és hazai tapasztalatok alapján a komplex üzleti hírszerzés - annak offenzív és defenzív területe - a letéteményese ennek a legmagasabb szintű vállalati biztonsági kultúra kialakításának. Természetesen ez nagymértékben tudja befolyásolni a benne részt vevő, illetve érintett személyek biztonsághoz való hozzáállását. Egy vállalaton, munkahelyi közösségen belül a biztonsági tudatformálás során meg kell élni azt és meg kell harcolni azért, hogy a fejekben eljussunk a „vállalati Gestapótól” a „megkerülhetetlenül szükséges” megítélésig és az ezzel kapcsolatos biztonsági szervezet és a biztonságrezsim elfogadásához.

\section{Terrorelhárítással kapcsolatos biztonságtudatosítás}

A terrorelhárítással kapcsolatos biztonságtudatosítás területén meg kell próbálni logikai sorba rendezni és eszerint felépíteni a munkánkat. Döntően kétfelé ágazik a munka, a megelőzés-felkészítés és a bekövetkezett események kezelése felé. 
a) Megelőzés-felkészités: általános tájékoztatás, információadás a megelőzés érdekében:

- a terrorizmus mint jelenség története, megjelenési formái, trendjei napjainkban;

- a terrorjellegü cselekmények bemutatása;

- a végrehajtási magatartások, ezek előkészületének felismerése, felismerhetősége, a ráutaló magatartások megismerése;

- a „veled is megtörténhet” gondolat elültetése;

- a terrorcselekményekkel kapcsolatos társadalomérzékenyítési munka a megfelelő szinteken, a szintekhez rendelt és illesztett tartalommal.

Iskoláskortól fontos, hogy a megfelelő formában foglalkozzunk azokkal a kérdésekkel, hogy „mire kell odafigyelni”, „mit kell észrevenni”, „kinek kell szólni”, valamint, „ha megtörténne, mit kell tenni”.

Ezekre a gyermek- és fiatalkorban lefektetett alapokra lehet később, már a munka és mindennapok felnőtt világában felépíteni a terrorcselekményekkel kapcsolatos további érzékenyítési feladatokat.

b) A bekövetkezett események kezelése: a „megtörtént és benne vagyunk” helyzet. A munka alapja ez esetben a világban megtörtént események folyamatos és gyors elemzése és értékelése, a jelenségek okainak és körülményeinek feltárása. Ezeket az információkat kell tudnunk ajánlott magatartási szabályokká, viselkedési tanácsokká konvertálni.

A terrormegelőzéssel foglalkozó szakemberek meggyőződése és egyben küldetése is az, hogy egy tartalmas, szakmailag megalapozott, érthető és a gyakorlatban felhasználható információs csomaggal segítsük az emberek mindennapjait. Ezzel kapcsolatban a TEK által kiadott Mindennapi biztonság címü kézikönyv ${ }^{9}$ (megelöző-védelmi ajánlások) letölthető a TEK honlapjáról e-book-formátumban. Előszavában Hajdu János r. altábornagy, a TEK főigazgatója így fogalmazott:

„Valami megváltozott Európában. A 2015 novemberében Párizsban kezdődött terrortámadás-sorozat alapjaiban átformálta a kontinens biztonsági viszonyait. A terrorszervezetek aktivitása, a rendszeres támadások, az elkövetői magatartások változása, a magányos elkövetők nagyobb számú megjelenése más típusú rendvédelmi válaszokat igényelt. Az elkövetők, a véghezvitt cselekmények körülményei, a támadott létesítmények és a rendezvények egyértelmüen jelzik, hogy fokozni kell a párbeszédet a társadalmi csoportokkal, és törekedni kell az állampolgári biztonságtudatosság kialakítására, gondozására."

A terrorelhárítással és -megelőzéssel kapcsolatos fejtegetések végéhez közeledve fontos megemlíteni egy dilemmát. Képletesen fogalmazva: a „mit miért” kell csinálni kérdés körvonalazódik, a „kinek és hogyan” kell megcsinálnia egyértelmú megválaszolása viszont még várat magára.

A TEK felderítő, elhárító szervezet, amely rendelkezik műveleti, felszámolói és kiemelt személyvédelmi képességekkel és kapacitásokkal. Jelenlegi szervezetében 
képes arra, hogy tapasztalataival, értékeléseivel, elemzéseivel támogassa a biztonságtudatosítás, a társadalmi érzékenyítés programját. Ennek megfelelő minőségi és főleg eredményes megvalósítása humán és egyéb erőforrásokat igényel. El lehetne gondolkodni azon, hogy ez az irány hogyan épülhetne be a TEK, illetve más nemzetbiztonsági, valamint rendvédelmi szervek életpályamodelljébe. Az évtizedek tapasztalatával rendelkező kollégáink garanciái lehetnének egy szakmailag hiteles, magas színvonalú, tudatformáló programnak. E téma kifejtése már egy következő cikkért kiált.

\section{A magánbiztonság esszenciális szerepe}

A rendszerváltást követő, elmúlt három évtized során a rendőrség, monopolhelyzetét elveszítve, identitásválságot is előidézett, miközben jónéhány magán- és közösségi rendészeti szervezetet termelt ki. A posztmodern átalakulás, a rendfenntartás pluralizmusa két dolgot jelentett egyszerre: egyrészt az állami rendészeti monopólium megtörését, másrészt a magánbiztonsági és polgári rendfenntartás előtérbe kerülését, jelentős növekedését. ${ }^{10} A$ szabad piacgazdaság és a magántulajdon rendszerváltást követő térnyerése és rohamos ütemben növekvő védelmi igénye pedig, szükségszerűen hívta létre az üzleti alapon működő, a közbiztonságot kiegészítő tevékenységű és a későbbiekben polgárjogot nyerő magánbiztonsági vállalkozásokat, amelyek - szakmai és üzleti tapasztalataik növekedésével - napjainkra egyre meghatározóbb jelentőséggel bírnak az érték- és vagyonvédelem valamennyi területén. A biztonsági ágazat léte és növekedése a bizonyiték arra, hogy az állampolgár saját kezébe veszi a biztonságáról való gondoskodást, ezzel visszaveszi a korábban az államra testált jogot. ${ }^{11}$

Figyelemre méltó, hogy Magyarország már 2008-ban azon tíz európai állam közé tartozott, ahol a piaci nyitás következtében nagyobb létszámban voltak jelen a magánbiztonsági szolgáltatók, mint az állami biztonsági szerveké. ${ }^{12}$ 2020-ban a hazai magánbiztonsági vállalkozások száma 6461, míg a kiadott személy- és vagyonőri igazolványok ${ }^{13}$ száma 96008 darab volt. ${ }^{14}$

Legyen bármennyire is felkészült egy magánbiztonsági szolgáltató, eredményességének legszúkebb keresztmetszetét a szolgáltatás leggyengébb láncszeme, a rész(ek) egészre való hatása adja, így a tevékenység stabilitása is - adott esetben - a leggyengébb elem erősségétől függhet. Ennek alapján el kell tudnunk érni, hogy a biztonság

$10 \quad$ Kerezsi Klára - Nagy Veronika: A rendészettudomány kritikai megközelítése. In Boda József - Felkai László - Patyi András (szerk.): Ünnepi kötet a 70 éves Janza Frigyes tiszteletére. Budapest, Dialóg Campus, 2017. 275.

11 Kerezsi Klára - Pap András László: A bűnözés és a bűnözéskontroll jövője. In Finszter Géza - Sabjanics István (szerk.): Biztonsági kihívások a 21. században. Budapest, Dialóg Campus, 2017. 573.

12 Tóth Judit: Közrendészeti magánbiztonság és magánrendészet közpénzből. Belügyi Szemle, 65. (2017), 5.

13 Vállalkozások (személy- és vagyonvédelmi, magánnyomozói, tervező-szerelő), igazolványosok (személyés vagyonőr, magánnyomozó, vagyonvédelmi rendszert tervező-szerelő, vagyonvédelmi rendszert szerelő).

14 Az Országos Rendőr-főkapitányság Rendészeti Főigazgatóság Igazgatásrendészeti Főosztály által biztosított, összesített, 2020. december 31-ei állapotnak megfelelő statisztikai adatok szerint. Christián László - Lippai Zsolt: Kakukktojás vagy új rendészeti alappillér? In „Tehetség, szorgalom, hivatás”: Tanulmánykötet. Budapest, Magyar Rendészettudományi Társaság Vám- és Pénzügyőri Tagozat, 2021. 18. 
mint termék megteremtésében érintett valamennyi szereplő azt sajátjának tekintse, annak folyamatában, kvázi biztonsági szakemberként vállalja magára a rá háruló részt. Egy professzionális magánbiztonsági szolgáltató az egyéni és kollektív biztonsági tudatosság erősítésével szinte észrevétlenül vonja be és teszi - a rá vonatkozó módon és mértékben - érdekeltté a tevékenységében érintett valamennyi személyt a biztonság közös érdekű megteremtésében, a vétkezés előre megakadályozása lehetőségének minimalizálásában.

\section{A biztonságtudatosság fejlesztése a magánbiztonságban}

Annak felismer(tet)ése, hogy a biztonság megteremtése mindenki felelőssége, amelyben csak közösen érhetünk el érdemleges eredményt, akár már félsikernek is tekinthető. Ugyanakkor fontos, hogy a tudatosság fejlesztését ne a direkt tények, a biztonsági direktívák ismertetésével kezdjük, hanem annak megértetésével, hogy tudatos magatartásunkkal a saját életünket és környezetünket, így családtagjaink, szeretteink életét is biztonságosabbá tehetjük. Értve ez alatt például a lakásajtónk bezárását, a közlekedési szabályok betartását, értékeink megfelelő védelmét, vagy akár az ATM-ből történő pénzfelvételünk körültekintő gondosságát, tehát a gondolkodásunk ilyen irányú átalakulását.

Tudatosítani kell az egyénben, hogy nincsen egyedül, és bár többnyire észrevétlenül, de mindig ott állunk mellette, mögötte, és mindenkor számíthat ránk. Rendelkezésére kell bocsátani az éjjel-nappal működő elérhetőségeinket és elmondani, nincsen felesleges jelzés, csak olyan van, amelyet ő fontosnak érez közös küldetésünk érdekében a tudomásunkra hozni. Ugyanakkor megmutatni azt is, hogy mit és hogyan kell tennie, ha harmadik fél kényszeríti az említett jelzés adására, azt hogyan tudja - saját veszélyeztetése nélkül - a tudomásunkra hozni.

A munkáltató által megkövetelt speciális biztonsági szabályokra a munka-, baleset-, tűz- és egészségvédelmi alapok elsajátítását követően érdemes komolyabb hangsúlyt fektetni, azt a már meglévő alapok kibővítésével kontextusba helyezni. Ez megvalósulhat jelenléti, e-learning vagy blended learning (tematikus, egy-egy témakört felölelő, például iratkezelési, titokvédelmi szabályok, munkahelyi erőszak felismerése stb.) képzések során, amelyek végrehajthatók szervezett munkahelyi körülmények vagy akár önképzés keretében is. A képzéseknek tematikusan egymásra épülően, a biztonság kérdését megfelelő szakmaisággal, a nem biztonsági szakemberek számára is érthető, feldolgozható módon, megtörtént, valós helyzetek elemzésével szükséges felépíteni.

A biztonsággal kapcsolatos intézkedéseket megfogalmazó tájékoztatásoknak, a kiadott brosúráknak, kifüggesztett tájékoztatóknak egyértelmű, egyszerú és biztos üzenetet/üzeneteket indokolt hordozniuk. Bemutatva a veszélyt jelentő vagy annak bekövetkezésére utaló helyzetek felismerésére és beazonosítására vonatkozó, egyértelmú tájékoztatásokat, illetőleg azt, hogy ezen esetekben pontosan mit, mikor és hogyan szükséges megtenni (például, hogy kapcsoljuk ki a számítógépünket, ha elhagyjuk a munkaállomásunkat, csak céges adathordozót csatlakoztassunk, zárjuk 
be az íróasztalunk, tárolószekrényünk fiókjait, vagy tűzriadó esetén merre hagyjuk el az épületet stb.).

\section{Esettanulmány: biztonságtudatosság a szállodákban}

Alan Orlob, a Marriott International ${ }^{15}$ szállodaipari óriáscég volt biztonsági igazgatója szerint figyelemmel kell kísérni a terrorizmus változásait és lépést tartani velük, csökkenteni a sebezhetőséget és a szükséges mértékben keményíteni a puha célpontokat. A védelmi intézkedéseket és eljárásokat a változó kockázatokhoz kell igazítani, és ahogy a terrorszervezetek fejlesztik a támadásaikat, a biztonsági szakembereknek fejleszteniük kell a megelőzésükre tett intézkedéseket. ${ }^{16}$

1990-ben, az Amerikai Egyesült Államok panamai invázióját követően Ed Fuller, ${ }^{17}$ a Marriott International egykori vezetője érezte először szükségét annak, hogy válságkezelési programot kell kidolgozni a szállodák számára, mert a Marriott szálloda vendégei - válságkezelési terv hiányában - a szálloda mosó- és szárítógépeiben rejtőztek el a panamai katonák elől. A vállalat válságkezelési stratégiájának újabb fordulópontját a 2001. szeptember 11-i terrortámadások jelentették, amikor - az amerikai Homeland Security Advisory System ${ }^{18}$-hez hasonlóan - létrehoztak egy veszélyeztetettségiszint-rendszert, amely öt kategóriába sorolta a veszélyeztetettséget, és a szintekhez kötelező biztonsági intézkedéseket határozott meg.

Felismerték annak tényét, hogy egy potenciális terrortámadás megelőzésében óriási előnyt jelenthet, ha a szálloda alkalmazottai is alapvető biztonságtudatossági ismeretekkel rendelkeznek, észreveszik és jelzik a biztonsági szolgálatnak, ha bármi rendellenességet tapasztalnak. Bár a vállalat szállodái a világ minden részén többnyire eltérő biztonsági környezetben működnek, bizonyos oktatási elemek mindegyikük esetében egyformán jelen vannak. Ezek közé tartozik egyebek közt a válságkezelési terv ${ }^{19}$ megismerése és annak tudatosítása, hogy biztonságtudatos magatartásukkal nemcsak a vendégeiket, de egymást is védik.

15 A Marriott International a világ legnagyobb szállodaipari vállalataként (több mint 6000 szálloda a világ 122 országában) élen jár a válsághelyzeti protokollok kidolgozásában.

16 Alan Orlob: Protecting soft targets in hostile environments. Recent attacks expose vulnerabilities. The Guardian, The Source of Antiterrorism Information, (2009), 11. 7.

A Marriott International volt elnöke, tanácsadó, szerző és előadó.

Az Amerikai Egyesült Államok belbiztonsági tanácsadó rendszere, egy színkóddal ellátott terrorizmus-fenyegetési tanácsadóskála volt.

19 Minden szálloda válságkezelési terve egyénre szabott, abban általános irányvonalakat lehet felvázolni, de az akár egy városon belüli szállodák között is lényeges eltérések lehetnek. Azok az elemek, amelyeknek célszerűen szerepelniük kellene valamennyi válságkezelési tervben az alábbiak:

- elérhetőségek (a központi szervezet, a szálloda vezetése, hatóságok, hibaelhárító és karbantartó cégek, beszállítók, hivatalok, nagykövetségek, szerződéses partnerek vagy bármilyen más szervezet vagy személy, akivel válsághelyzet esetén szükséges vagy lehet kapcsolatba lépni);

- értesítési eljárás (ki kit, milyen esetben, miért és hogyan fog értesíteni);

- a szállodában tartózkodó személyek (hogyan állapítható meg bármelyik pillanatban, hogy hányan és kik tartózkodnak a szállodában [vendégek, alkalmazottak, látogatók stb.]);

- a szálloda válságkezelési szervezetei, azok felépítése, múködése, felelőssége;

- hol legyen a szállodában látható biztonsági személyzet (visszatartó erő);

- stratégiai pontok válsághelyzet esetén (vezetési pont, kiürítési pont, belső kiürítési pont, befogadó pontok és mindezek másodlagos vagy harmadlagos helyszínei); 
A személyzet tagja az első biztonsági ismereteket átadó képzést a felvételét követően, de még munkába lépése előtt kapja meg, amely oktatás alapesetben évente egyszer, két óra időtartamban, illetőleg speciális ismeretek átadásának szükségessége - például rendkívüli események, terrortámadások bekövetkezése - esetén három-négy óra időtartamban, a munkaidő terhére valósul meg.

Az oktatások során a szállodalánc által, egységes szempontrendszer alapján felkészített - sok esetben rendészeti, harctéri, terrorelhárítási gyakorlattal rendelkező - magánbiztonsági szakemberek tudatosítják a személyzetben egy esetleges támadás veszélyeit, következményeinek súlyosságát, és felhívják a figyelmüket, hogy a megszerzett ismeretek és azok alkalmazása a magánéletükben is előnyössé válhatnak. A képzések személyre szabottan, az adott beosztásnak megfelelő általános és speciális ismeretek készségszintű elsajátítását célozva tartalmazzák a szálloda krízismenedzsmenttervének és biztonsági protokolljainak ismertetését, a vészhelyzeti teendőket, az elkövetők módszereit és azok felismerését, valamint beszélnek a terrorizmus átalakulásáról, az új típusú veszélyekről, azok felismeréséről és jelzéséről. Megfelelő felkészítés esetén ugyanis ez a személyzet fogja képezni a szálloda biztonságának egyik hatékony jelzőrendszeri pillérét, ők lesznek azok, akiknek először feltűnik, ha a közvetlen munkakörnyezetükben bármi változás vagy gyanús esemény történik, hiszen ők ismerik legjobban az adott környezetet. ${ }^{20}$

A képzés kiemelt elemeként szerepel az egyes büncselekményi kategóriák elkövetésének, valamint az azok elkövetésére történő előkészítő cselekmények felismerésének, többnyire megtörtént esetek, ${ }^{21}$ illetőleg a Mariott munkatársai által elkészített, alábbi témákat feldolgozó oktatófilmek bemutatása és az adott munkakörnek megfelelő elemzése:

- ismeretlen személyek hosszabb ideig vagy visszatérően megjelennek az épület körül;

- elhagyott gépjármú az épület környezetében;

- rendszámtábla nélkül vagy piszkos, nem látható rendszámtáblával érkező jármű;

- túlsúlyos jármú;

- csomagok nélkül, vagy feltűnően sok vagy nehéz csomaggal érkező szállóvendég;

- az időjáráshoz képest feltúnően vastag ruházatban lévő személy;

- elhagyott csomag a szálloda területén;

- gyakorlatok válsághelyzetre való felkészülésre (hogyan, mire és milyen gyakorisággal);

- az épülettel kapcsolatos információk (az épület szerkezetéről, az elektromos, légtechnika-, gáz-, víz-, informatikai, biztonságtechnikai, kommunikációs stb. rendszerekről);

- válsághelyzeti tartalékok (mi, hol és milyen mennyiségben);

- események rögzítése (mikor, hogyan és ki által);

- biztonsági protokollok konkrét vészhelyzetekre (természeti csapások, bűncselekmények, tǔz, robbanás, zavargás, kiürítés, műszaki meghibásodások, balesetek, egészségügyi vészhelyzetek, terrorcselekmények);

- károk felmérése és helyreállítás (hogyan, miből, ki által, mennyi idő alatt).

20 Lippai Zsolt - Thieme-Eső Milán: A szállodák, mint „puha célpontok”. In Közös kihívások-egykor és most. Tanulmánykötet. Budapest, Magyar Rendészettudományi Társaság Vám- és Pénzügyőri Tagozat, 2020. 175.

21 Értve ez alatt a Mariott szállodalánc elleni, már bekövetkezett terrorcselekmények (Pakisztán Islamabad 2008. 56 halott, 265 sérült; Amman Jordánia 2005. 60 halott, 115 sérült; Mumbai India 2008. 166 halott, több mint 300 sérült) eredeti felvételei, valamint a cselekmények előkészületének, végrehajtásának, utóéletének és egy lehetséges terroristatámadási ciklus részletes elemzését. 
- vendég, aki készpénzzel fizet olyan nagyobb tételekért, amelyekért rendszerint bankkártyával szokás fizetni;

- ha bárki nem vendég számára szükséges információkat kérdez a személyzettől;

- az épületet fényképező vagy arról rajzokat készítő személyek;

- vendégszobában hagyott nagyobb mennyiségü készpénz, térképek, alaprajzok, kábelek, elemek, fém alkatrészek, vegyszerek, lőszerek, lőfegyver vagy lőfegyveralkatrészek, rádiókommunikációs eszközök;

- "Ne zavarjanak" tábla kitéve az ajtóra 24 óránál hosszabb ideig;

- idegen személyek üzemi területen azonosító nélkül stb.22

Itt kell megemlítenem a szállodalánc „See something? Say something!” azaz „Látsz valamit? Mondj valamit!” programját, amelynek alapjait a személyzet valamennyi tagja az ismétlődő oktatások során sajátítja el. A program részeként a vendégtértől elzárt, a szálloda személyzete által bejárt részeken figyelemfelhívó színes ábrák vannak elhelyezve a biztonságtudatossági képzés főbb elemeit tartalmazó képekkel és azok szöveges magyarázatával. Egy a szállodai vendégtérben elhagyott csomag fotója alatt például a szöveg: „Elhagyott csomag”, illetőleg fegyver, kábítószer vagy gyanús tárgyak fényképe és leírása stb.

Összegzésképpen elmondható, hogy - a biztonság komplex és sokrétű jellegének megfelelően - a biztonsági tudatosítás során a nemzetbiztonsági, terrorelhárítási és magánbiztonsági szervek hasonló módszertan alapján és hasonló vagy sok esetben azonos célok elérése érdekében tevékenykednek. Érzékenyítő tevékenységük során átvehetik és testreszabhatják egymás módszereit. Munkájuk ezzel együtt vagy ettől függetlenül egymást kiegészít(het)i és támogat(hat)ja. Tevékenységük együtt vezet el mindannyiunk nagy becsben tartott közös kincséhez: a komplex biztonsághoz.

\section{Felhasznált irodalom}

Christián László - Lippai Zsolt: Kakukktojás vagy új rendészeti alappillér? In „Tehetség, szorgalom, hivatás": Tanulmánykötet. Budapest, Magyar Rendészettudományi Társaság Vám- és Pénzügyőri Tagozat, 2021. Online: https://doi.org/10.37372/ mrttvpt.2021.1.1

Görgényi Ilona - Gula József - Horváth Tibor - Jacsó Judit - Lévay Miklós - Sántha Ferenc-Csemáné Váradi Erika: Magyar büntetőjog általános rész. Budapest, 2019.

Kádár Gyula: A Ludovikától Sopronkőhidáig. Budapest, Magvető, 1984.

Kerezsi Klára - Nagy Veronika: A rendészettudomány kritikai megközelítése. In Bofa József - Felkai László - Patyi András (szerk.): Ünnepi kötet a 70 éves Janza Frigyes tiszteletére. Budapest, Dialóg Campus, 2017.

Kerezsi Klára - Pap András László: A bűnözés és a bűnözéskontroll jövője. In Finszter Géza - Sabjanics István (szerk.): Biztonsági kihívások a 21. században. Budapest, Dialóg Campus, 2017. 
Lippai Zsolt - Thieme-Eső Milán: A szállodák, mint „puha célpontok”. In Közös kihívások-egykor és most. Tanulmánykötet. Budapest, Magyar Rendészettudományi Társaság Vám- és Pénzügyőri Tagozat, 2020. Online: https://doi.org/10.37372/ mrttvpt.2020.1.9

Orlob, Alan: Protecting soft targets in hostile environments. Recent attacks expose vulnerabilities. The Guardian, The Source of Antiterrorism Information, (2009), 11. Online: www.hsdl.org/?view\&did=706275

Tóth Judit: Közrendészeti magánbiztonság és magánrendészet közpénzből. Belügyi Szemle, 65. (2017), 5. 5-24. Online: https://doi.org/10.38146/BSZ.2017.5.1 